\title{
Production of schizophyllan from distiller's dried grains with solubles by diverse strains of Schizophyllum commune
}

\author{
Nongnuch Sutivisedsak, Timothy D Leathers ${ }^{*}$ and Neil PJ Price
}

\begin{abstract}
Eleven diverse strains of Schizophyllan commune were examined for production of the biopolymer schizophyllan from agricultural biomass. Strains were grown in malt extract (ME) basal medium containing $1 \%(\mathrm{~W} / \mathrm{v})$ distiller's dried grains with solubles (DDGS), an abundant coproduct of fuel ethanol production by the dry grind process. Ten of 11 strains tested produced more than $2 \mathrm{~g}$ schizophyllan/L. Two strains, ATCC 20165 and CBS 266.60, produced more than $10 \mathrm{~g}$ schizophyllan/L. Schizophyllan from these strains was similar to commercial product in terms of solution viscosity, molecular weight, and surface tension properties, suggesting that they would be equivalent in biomaterial applications.
\end{abstract}

Keywords: Distiller's dried grains with solubles; DDGS; Schizophyllum commune; Schizophyllan

\section{Background}

Schizophyllan is a homoglucan with a $\beta$-1,3-linked backbone and single $\beta-1,6$-linked glucose side chains at every third residue (Figure 1), produced by the fungus Schizophyllum commune (Rau 1999; Rau 2002). Schizophyllan is commercially produced for use in anticancer therapies and as a bioactive cosmetics ingredient (Rau 2002). However, schizophyllan also has unique physical properties of high viscosity, film formation, and thermal stability that suggest bulk biomaterials applications. Schizophyllan can form oxygen-impermeable films for food preservation (Schulz et al. 1992), and it has been tested for use in enhanced petroleum recovery (Rau et al. 1992b).

Although glucose is used in conventional production of schizophyllan, $S$. commune can utilize a number of sugars and agricultural residues for polysaccharide production (Steiner et al. 1987; Leathers et al. 2006; Gao and Zhou 2008; Kumari et al. 2008; Shu and Hsu 2011). Inexpensive agricultural biomass residues could be appropriate for production of

\footnotetext{
* Correspondence: Tim.Leathers@ars.usda.gov

Renewable Product Technology Research Unit, National Center for Agricultural Utilization Research, Agricultural Research Service, U.S.

Department of Agriculture, 1815 North University Street, Peoria, IL 61604,
} USA

schizophyllan for biomaterials applications. Schizophyllan could fit into the integrated biorefinery concept as a value-added bioproduct from biomass. One readily available type of agricultural biomass is distiller's dried grains with solubles (DDGS), an abundant coproduct of fuel ethanol production from corn by the dry-grind process (Rosentrater et al. 2012). We recently demonstrated the efficient utilization of DDGS for schizophyllan production by $S$. commune commercial production strain ATCC 38548 (Sutivisedsak et al. 2013).

Despite the fact that $S$. commune is an ubiquitous mushroom found world-wide, commercial production and most research studies have involved a single strain, ATCC 38548 (Prokop et al. 1992; Rau et al. 1992a; Sanroman and Nunez 1993; Shu and Hsu 2011). Few additional strains have been studied for schizophyllan production, such as NRCM and CGMCC 5.113 (Kumari et al. 2008; Li et al. 2011). In the current study we compare 11 diverse strains of $S$. commune for their ability to produce schizophyllan in medium containing DDGS. 


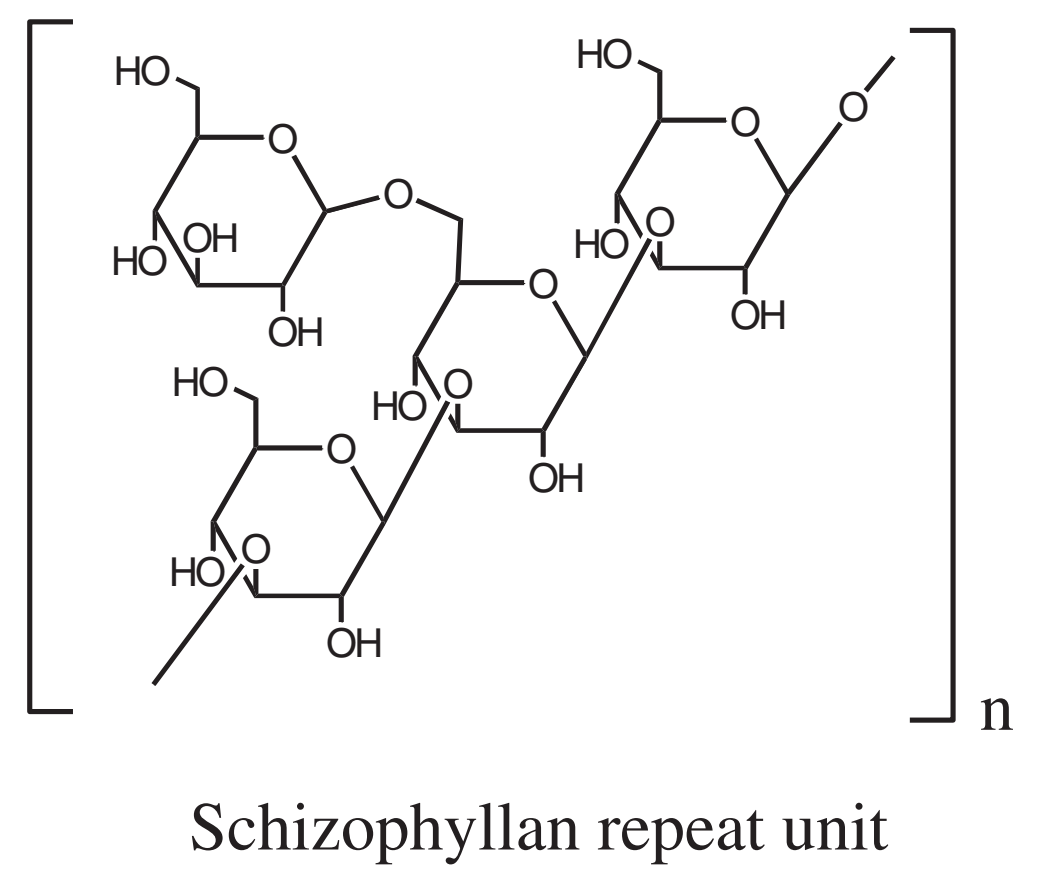

Figure 1 Chemical structure of the schizophyllan repeat unit.

\section{Results and discussion}

\section{Production of schizophyllan by diverse strains of}

\section{Schizophyllum commune}

A set of $11 S$. commune strains was chosen for this study, representing diverse isolation sources and sites (Table 1). Only non-clinical isolates were used because the goal was to identify strains with potential for industrial production. Ten of these strains produced more than $2 \mathrm{~g}$ schizophyllan/L in ME basal medium containing $1 \%$ (w/v) DDGS (Table 2). Thus, the capacity to produce schizophyllan from agricultural biomass appears to be a common trait among strains of S. commune. Two of these strains, ATCC 20165 and CBS 266.60, produced more than $10 \mathrm{~g}$ schizophyllan/L (Table 2). These yields are comparable to those obtained from commercial production strain ATCC 38548 (Sutivisedsak et al. 2013). Schizophyllan preparations from strains ATCC 20165 and CBS 266.60 were further examined for solution viscosity, molecular weight, and surface tension properties.

Table 1 Strains of Schizophyllum commune used in this study

\begin{tabular}{|c|c|c|c|c|c|}
\hline Strain & Substrate of isolation & Depositors & Country & Designation & Synonym \\
\hline ATCC 20165 & & Kyowa Ferm. Ind. Co., Ltd. & & $6 \mathrm{~F} 2$ & \\
\hline ATCC 26262 & & CA Raper & & 699 & \\
\hline ATCC 26890 & & Y Koltin & & 700 & \\
\hline ATCC 28095 & Loblolly pine log & ER Toole & & R-8 & \\
\hline ATCC 44200 & & J.G.H. Wessels, Jun 1981 & USA & $4-39$ & CBS 341.81 \\
\hline CBS 199.27 & Conserved stem, Hevea & A. van Luijk, Koloniaal Inst., May 1927 & & & MUCL 1008 \\
\hline CBS 249.69 & In sawmill, Intsia bijuga & M.R. Monsalud, Univ. of the Philippines, Mar 1969 & Philippines & & Daedalea elegans, FPRI10 \\
\hline CBS 266.60 & Mahogany wood & IMI, Mar 1960 & UK & & FPRL 9, IMI 061312 \\
\hline CBS 579.83 & Decaying jute cutting & H. Esterbauer, Oct 1983 & & & \\
\hline CBS 109645 & Litter & López, Aug 2001 & Colombia & & \\
\hline NRRL A-23867 & & P.A. Lemke & & & \\
\hline ATCC 38548 & Elm twig & M.G. Paice & & Delmar & \\
\hline
\end{tabular}


Table 2 Total biomass and production of schizophyllan (dry weights) by strains of Schizophyllum commune ${ }^{\mathrm{a}}$

\begin{tabular}{lcc}
\hline Strain & Total biomass (g/l) & Schizophyllan (g/l) \\
\hline ATCC 20165 & $6.4 \pm 0.5$ & $10.1 \pm 0.7$ \\
ATCC 26262 & $8.7 \pm 0.1$ & $8.3 \pm 0.5$ \\
ATCC 26890 & $12.4 \pm 0.4$ & $5.9 \pm 0.5$ \\
ATCC 28095 & $9.4 \pm 0.5$ & $2.2 \pm 0.2$ \\
ATCC 44200 & $13.2 \pm 0.2$ & $0.6 \pm 0.1$ \\
CBS 199.27 & $10.7 \pm 0.5$ & $2.4 \pm 0.1$ \\
CBS 249.69 & $11.5 \pm 0.4$ & $3.4 \pm 0.1$ \\
CBS 266.60 & $4.7 \pm 0.8$ & $12.7 \pm 0.1$ \\
CBS 579.83 & $12.3 \pm 0.1$ & $2.1 \pm 0.2$ \\
CBS 109645 & $13.2 \pm 0.4$ & $2.1 \pm 0.1$ \\
NRRL A-23867 & $10 \pm 0.1$ & $2.3 \pm 0.2$ \\
\hline
\end{tabular}

${ }^{a}$ Cultures grown for 8 days on $1 \%(\mathrm{w} / \mathrm{v})$ distiller's dried grains with solubles (DDGS) in malt extract basal medium.

\section{Properties of schizophyllan solutions from S. commune} strains ATCC 20165 and CBS 266.60

Schizophyllan from S. commune strains ATCC 20165 and CBS 266.60 was structurally analyzed by Heteronuclear Single Quantum Coherence-NMR (Figure 2). The spectra were essentially identical to those of both a commercial schizophyllan standard and schizophyllan from commercial strain ATCC 38548. Spectra showed two anomeric sugar signals at $4.55 \mathrm{ppm}$ and $4.20 \mathrm{ppm}$, due to the $\beta$-1,3-linked glucose and $\beta-1,6$-linked glucose, respectively. These signals correlated to overlapping ${ }^{13} \mathrm{C}$ signals at $103.4 \mathrm{ppm}$, consistent with $\beta$-linked glucosyl residues. Other carbohydrate signals were apparent in the $2.7-4.0 \mathrm{ppm}$ region for ${ }^{1} \mathrm{H}$, and $55-$ $85 \mathrm{ppm}$ for ${ }^{13} \mathrm{C}$ nuclei. Characteristic methylene $\mathrm{CH}_{2}$ signals were apparent at 3.40 and $3.60 \mathrm{ppm}$, coupled to a single ${ }^{13} \mathrm{C}$ signal at $61 \mathrm{ppm}$. These were assigned to the C-6 position of the backbone glucose residues carrying a 1,6-glucose branch. These data are consistent with the isolated polysaccharides being schizophyllan.

The solution viscosity properties of $0.3 \%(\mathrm{w} / \mathrm{v})$ aqueous solutions of schizophyllan from strains ATCC 20165 and CBS 266.60 were compared with those of commercial strain ATCC 38548 (Figure 3). These strains exhibited nearly identical viscosity and shear thinning properties, characteristic of the pseudoplastic flow behavior of schizophyllan solutions (Rau 1999).

HPSEC was used to characterize the molecular weight of schizophyllan. Schizophyllan produced by S. commune strains ATCC 20165 and CBS 266.60 exhibited heterodisperse peaks with maximum molecular weights of $4.6 \times 10^{6}$ and $5.2 \times 10^{6}$, respectively. The values are consistent with literature values of $6-12 \times 10^{6}$ (Rau 1999).

The interfacial tension of $0.3 \%(\mathrm{w} / \mathrm{v})$ aqueous solutions of schizophyllan from S. commune strains ATCC 20165 and CBS 266.60 were $52 \pm 1.9$ and $55 \pm 2.8 \mathrm{dy} / \mathrm{cm}$, respectively (standard deviations shown). By comparison, schizophyllan from commercial strain ATCC 38548 showed similar values of $58 \pm 3.5 \mathrm{dy} / \mathrm{cm}$, while pure water exhibits an interfacial tension of $72 \mathrm{dy} / \mathrm{cm}$ (Dunlap et al. 2011). Thus, schizophyllan solutions from strains ATCC 20165 and CBS 266.60 showed relatively low surface activity, similar to commercial preparations (Rau 1999).

\section{Conclusions}

Ten of 11 diverse strains of $S$. commune produced schizophyllan from agricultural biomass. Two of these strains, ATCC 20165 and CBS 266.60, produced yields comparable to those from a commercial production strain. The physical properties of schizophyllan solutions from these strains also were comparable to those of commercial schizophyllan, suggesting that they would be equivalent in biomaterial applications.

\section{Methods}

\section{Strains and culture conditions}

Schizophyllum commune strains used in this study were obtained from the American Type Culture Collection, Manassas, VA (ATCC strains), the ARS Culture Collection at the National Center for Agricultural Utilization Research, Peoria IL (NRRL strain) and the Centraalbureau voor Schimmelcultures, Utrecht, The Netherlands (CBS strains). Malt extract (ME) basal medium contained $2 \%(\mathrm{w} / \mathrm{v})$ malt extract and $0.1 \%$ $(\mathrm{w} / \mathrm{v})$ peptone. Strains were grown on $\mathrm{ME}$ solid medium containing $2 \%(\mathrm{w} / \mathrm{v})$ glucose and $2.5 \%(\mathrm{w} / \mathrm{v})$ agar at $28^{\circ} \mathrm{C}$ for $7-10$ days. A $7 \mathrm{~mm} \times 7 \mathrm{~mm}$ square of mycelium was used to inoculate $250 \mathrm{~mL}$ of ME basal medium containing 2\% (w/v) glucose in a $500 \mathrm{ml}$ fluted Erlenmeyer flask with three $10 \mathrm{~mm}$ glass beads. This preinoculum culture was incubated at $240 \mathrm{rpm}$ for $4-5$ days at $30^{\circ} \mathrm{C}$. Experimental cultures containing $1 \%(\mathrm{w} / \mathrm{v})$ of DDGS in $150 \mathrm{~mL}$ of ME basal medium (without glucose) in $500 \mathrm{~mL}$ flasks were inoculated with $1.5 \mathrm{~mL}$ of preinoculum $(1 \% \mathrm{v} / \mathrm{v})$ and incubated at $240 \mathrm{rpm}$ for 8 days at $30^{\circ} \mathrm{C}$. DDGS was obtained from the National Corn-to-Ethanol Research Center, Edswardville, IL. All experiments were carried out in triplicate and standard deviations are shown. 

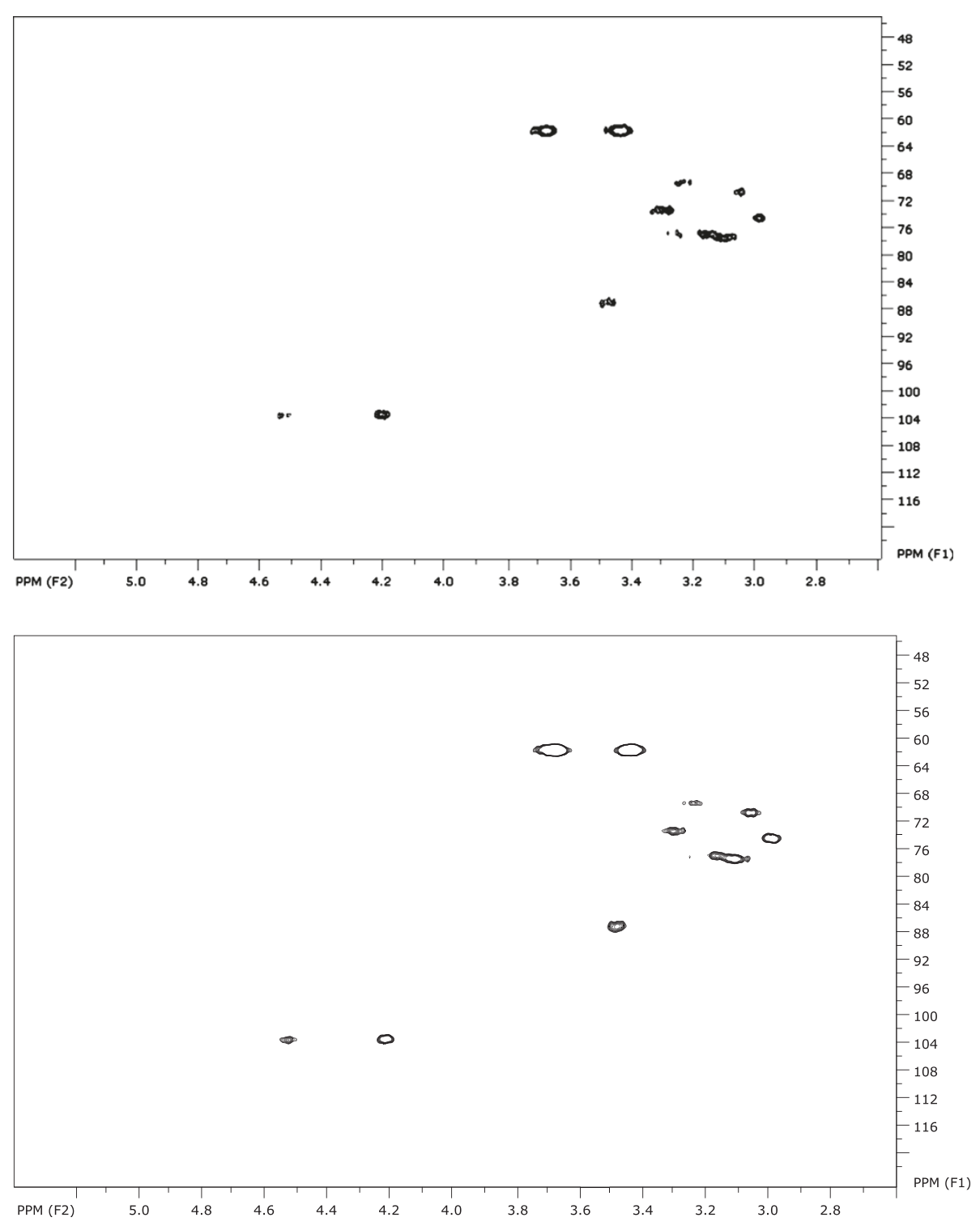

Figure 2 HSQC 2D-NMR spectra of schizophyllans from strains CBS 266.6 (top) and ATCC 20165 (lower).

\section{Isolation of schizophyllan}

Whole culture suspensions were homogenized for $20 \mathrm{sec}$ (Power Gen 700, Fisher Scientific) and centrifuged at $6,166 \times \mathrm{g}$ for $1 \mathrm{~h}$ at $4^{\circ} \mathrm{C}$. The supernatants were collected and the insoluble pellets (containing mycelia and residual DDGS) were resuspended in $100 \mathrm{~mL}$ of deionized water, homogenized, and centrifuged as before. The pellets were dried under vacuum for $48 \mathrm{~h}$ at $60^{\circ} \mathrm{C}$. The supernatants were combined and one volume of $95 \%$ ethanol was added. After $1 \mathrm{~h}$ at $4^{\circ} \mathrm{C}$, precipitates were collected by centrifugation at $6,166 \times \mathrm{g}$ for $1 \mathrm{~h}$ at $4^{\circ} \mathrm{C}$, air-dried overnight to reduce the amount of ethanol, and then lyophilized.

\section{NMR analysis}

Solution NMR spectra were recorded on a Bruker AMX 500 spectrometer at normal probe temperature with standard instrument settings. Deuterated dimethylsulfoxide (d6-DMSO) was used as the solvent. All chemical shifts were referenced to tetramethylsilane at 0 ppm. 


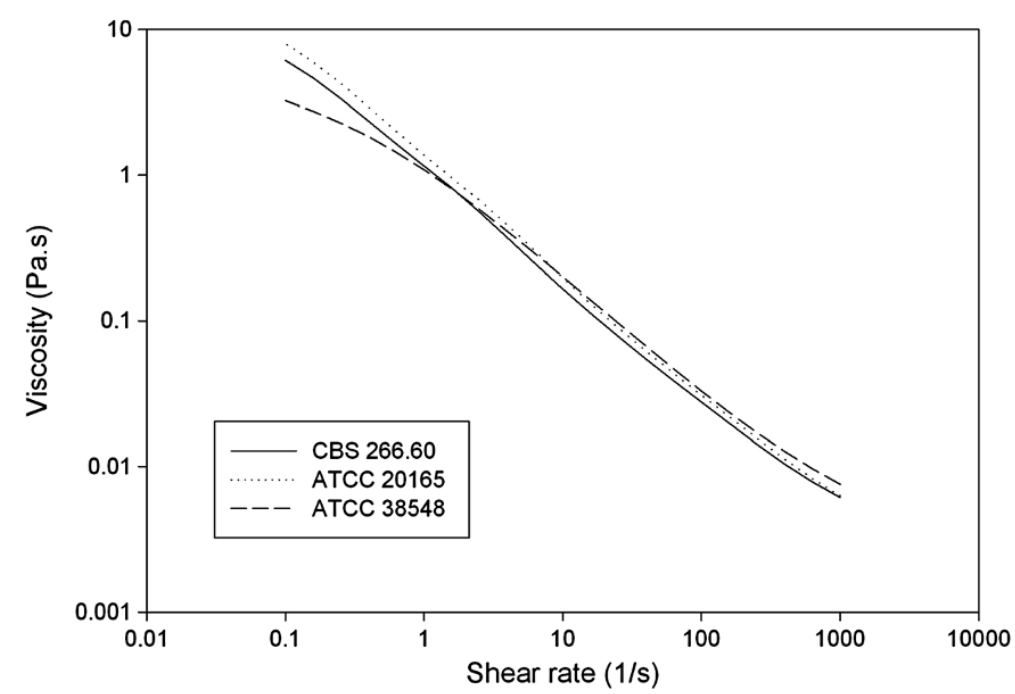

Figure 3 Solution viscosity properties of $0.3 \%(w / v)$ aqueous solutions of schizophyllan produced by Schizophyllum commune on DDGS in ME basal medium.

\section{Molecular weight determinations}

Schizophyllan molecular weights were determined by size exclusion chromatography as previously described, using a Shodex SB-806 M high performance size exclusion chromatography (HPSEC) column (Showa Denko, Tokyo, Japan) and eluted with $0.05 \mathrm{M}$ sodium nitrate at a flow rate of $0.5 \mathrm{ml} / \mathrm{min}$ (Leathers et al. 2010). The column was calibrated with a set of eight pullulan molecular weight standards ranging from $5.8 \times 10^{3} \mathrm{Da}$ to $1.66 \times 10^{6} \mathrm{Da}$ (Showa Denko, Tokyo, Japan). Separations were monitored using a Shodex OR-1 optical rotation detector (Showa Denko).

\section{Solution viscosity properties}

Solution viscosity was measured using a TA Instruments (New Castle, DE) ARES LS-1 controlled strain rheometer with a $25 \mathrm{~mm}$ titanium parallel plate. All tests were performed at $25^{\circ} \mathrm{C}$ using a peltier plate. Steady rate sweeps were used to determine the viscosity of samples from $0.01-100 \mathrm{~s}^{-1}$. The Cross model was used to determine the zero shear viscosity, which was 460 Pa.s.

\section{Surface activity}

Surface activity was determined using the pendant drop method (Dunlap et al. 2011). Samples were analyzed using the FTA 4000 surface tension instrument (First Ten Angstorms Inc., USA). Measurements were made using 22 gauge blunt needles with $7 \mu \mathrm{L}$ drops. The reported values are the average of triplicate cultures.

\section{Abbreviations}

DDGS: Distiller's dried grains with solubles; d6-DMSO: Deuterated dimethylsulfoxide; HPSEC: High performance size exclusion chromatography; ME: Malt extract basal medium; NMR: Nuclear magnetic resonance; USDA: United States Department of Agriculture.

\section{Competing interests}

The authors declare that they have no competing interests.

\section{Authors' contributions}

$N S$, TL, and NP participated in the conception and design of the study, interpreted experimental results, and helped draft the manuscript. NS produced and characterized schizophyllan from diverse strains of Schizophyllum commune. NP conducted the NMR studies of schizophyllan from selected strains and controls. All authors read and approved the final manuscript.

\section{Acknowledgements}

Expert technical assistance was provided by Erika Hertenstein, Melinda S. Nunnally, Suzanne Unser, and Andrew J. Thomas. The authors sincerely thank Christopher Dunlap for surface tension measurements. This project was supported by Agriculture and Food Research Initiative Competitive Grant no. 2010-65504-20377 from the USDA National Institute of Food and Agriculture. Mention of any trade names or commercial products in this publication is solely for the purpose of providing specific information and does not imply recommendation or endorsement by the US Department of Agriculture. USDA is an equal opportunity provider and employer.

Received: 30 May 2013 Accepted: 19 September 2013

Published: 22 September 2013

\section{References}

Dunlap CA, Schisler DA, Price NP, Vaughn SF (2011) Cyclic lipopeptide profile of three Bacillus subtilis strains; antagonists of Fusarium head blight. J Microbiol 49:603-609

Gao L, Zhou S (2008) Optimization of extraction technology of schizophyllan produced by solid fermentation. Shipin Gongye Keji 29:214-216

Kumari M, Survase SA, Singhal RS (2008) Production of schizophyllan using Schizophyllum commune NRCM. Biores Technol 99:1036-1043 
Leathers TD, Nunnally MS, Price NP (2006) Co-production of schizophyllan and arabinoxylan from corn fiber. Biotechnol Lett 28:623-626

Leathers TD, Nunnally MS, Cote GL (2010) Optimization of process conditions for enzymatic modification of alternan using dextranase from Chaetomium erraticum. Carbohydr Pol 81:732-736

Li W, Zhou P, Yu L (2011) Statistical optimization of the medium composition by response surface methodology to enhance schizophyllan production by Schizophyllum commune. Zeitschrift Naturforschung C J Biosci 66:173-181

Prokop A, Rapp P, Wagner F (1992) Production of extracellular $\beta-1,3 / \beta-1,6-g$ lucan by mono- and dikaryons of Schizophyllum commune. Exp Mycol 16:197-206

Rau U (1999) Production of schizophyllan. In: Bucke C (ed) Methods in biotechnology, vol 10, carbohydrate biotechnology protocols. Humana Press, Totowa, pp 43-55

Rau U (2002) Schizophyllan. In: Vandamme EJ, De Baets S, Steinbuchel A (ed) Biopolymers, vol 6, polysaccharides II: polysaccharides from eukaryotes. Wiley-VCH, Weinheim, pp 61-91

Rau U, Gura E, Olszewski E, Wagner F (1992a) Enhanced glucan formation of filamentous fungi by effective mixing, oxygen limitation and fed-batch processing. J Ind Microbiol 9:19-26

Rau U, Haarstrick A, Wagner F (1992b) Suitability of schizophyllan solutions for polymerflooding of petroleum reservoirs with high temperature and stability. Chemie Ingenieur Technik 64:576-577

Rosentrater KA, lleleji K, Johnston DB (2012) Manufacturing of fuel ethanol and distillers grains - current and evolving processes. In: Liu K, Rosentrater KA (ed) Distillers Grains: Production, Properties, and Utilization. CRC Press, Boca Raton, pp 73-102

Sanroman MA, Nunez MJ (1993) Production of extracellular polysaccharides. Anales de la Asociacion Quimica Argentina 81:15-23

Schulz D, Rau U, Wagner F (1992) Characteristics of films prepared from native

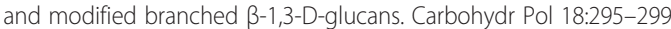

Shu C, Hsu H (2011) Production of schizophyllan glucan by Schizophyllum commune ATCC 38548 from detoxificated hydrolysate of rice hull. J Taiwan Inst Chem Eng 42:387-393

Steiner W, Lafferty RM, Gomes I, Esterbauer H (1987) Studies on a wild strain of Schizophyllum commune: cellulase and xylanase production and formation of the extracellular polysaccharide schizophyllan. Biotechnol Bioeng 30:169-178

Sutivisedsak N, Leathers TD, Nunnally MS, Price NPJ, Biresaw G (2013) Utilization of agricultural biomass in the production of the biopolymer schizophyllan. J Ind Microbiol Biotechnol 40:105-112

doi:10.1186/2193-1801-2-476

Cite this article as: Sutivisedsak et al: Production of schizophyllan from distiller's dried grains with solubles by diverse strains of Schizophyllum commune. SpringerPlus 2013 2:476.

\section{Submit your manuscript to a SpringerOpen ${ }^{\circ}$ journal and benefit from:}

- Convenient online submission

- Rigorous peer review

- Immediate publication on acceptance

- Open access: articles freely available online

- High visibility within the field

- Retaining the copyright to your article

Submit your next manuscript at $\gg$ springeropen.com 